\title{
PENERAPAN ASPEK IKLIM TROPIS PADA ARSITEKTUR LOKAL RUMAH TRADISIONAL MELAYU STUDI KASUS DI DESA LALANG SIAK SRI INDRAPURA
}

\author{
Boby Samra ${ }^{(1)}, \operatorname{Imbardi}^{(2)}$ \\ boby@unilak.ac.id, Imbardi@unilak.ac.id \\ (1), (2)Staf Pengajar Program Studi Arsitektur Fakultas Teknik \\ Universitas Lancang Kuning, Jl.Yos Sudarso km 8 Pekanbaru, Indonesia, 28265 \\ Tel/Fax: +62761 52324
}

\begin{abstract}
Abstrak
Rumah melayu adalah sebuah wujud dari bangunan yang memiliki makna sangat dalam oleh setiap orang melayu, bangunan tersebut merupakan perwujudan dari rasa tanggung jawab seorang kepala keluarga untuk memberikan keyamana bagi keluarganya. Pada saat bangunan tersebut dibangun tentunya banyak hal yang harus dipertimbangkan, seperti pertimbangan aspek lingkungan itu sendiri salah satunya iklim tropis, yang merupakan adanya pengaruh pencahayaan sinar matahari dan curah hujan terhadap ruang pada arsitektur lokal rumah tradisional Melayu. Dengan melakukan analisis terhadap bentuk bangunan serta bukaan pada dinding dalam bentuk jendela, ventilasi dan bentuk ornamen pada bangunan tradisional tersebut. Sehingga dapat di ketahui pengaruh fisik bangunan tersebut terhadap ruang dalam, sebagai bentuk kenyamanan penghuni untuk bisa menikmati kenyaman udara dan cahaya yang ada dalam ruang tersebut.
\end{abstract}

Kata Kunci: Arsitektur tradisional, Iklim tropis, Rumah Melayu.

\begin{abstract}
Abstrct
Malay house is a building that has a very important meaning by every Malay person, the building is a manifestation of the sense of responsibility of a head of the family to give understanding to his family. When the building is built, of course many things must be considered, such as consideration of the environmental aspect itself, one of them is the tropical climate, which is the influence of sunlight and rainfall on space in the local architecture of traditional Malay houses. By analyzing the shape of the building and openings in the wall in the form of a window, ventilation and shape of ornaments on the traditional building. So that you can know the physical effect of the building on the inner space, as a form of comfort for residents to be able to enjoy the comfort of air and light in the room.
\end{abstract}

Keywords: traditional architecture, tropical climate, Malay house.

\section{Pendahuluan}

Masyarakat melayu menilai hakikat rumah memiliki fungsi ganda, yakni sebagai tempat diam, tempat berkumpul keluarga, kaum kerabat dan handai taulan, tempat berteduh sanak saudara, tempat beranak berketurunan, selain itu rumah juga berfungsi sebagai tempat beradat berlembaga, sebagai simbol tanggung jawab seseorang terhadap keluarganya, simbol tuah dan marwah, simbol harkat dan martabat (Tenas Efendi, 2002)

Sebagai seorang masyarakat melayu kepala keluarga haruslah punya tanggung jawab yang besar, untuk memiliki sebuah rumah yang bisa di tempati bagi keluarganya, rumah tersebut haruslah memberikan rasa nyaman bagi dirinya dan seluruh keluarganya. rumah merupakan 
tempat mereka meristirahat serta melakukan aktifitas kegiatan sehari-hari selain diluar rumah.

Dengan aktifitas yang sangat banyak dalam menjalankan kehidupan sehari-hari, maka seluruh aktifitas tersebut tidak sepenuhnya bisa diselenggarakan di luar, ini dikarenakan oleh iklim tropis yang berlaku pada kawasan Indonesia pada khususnya pulau Sumatera. Dengan di buatnya sebuah bangunan untuk melaksanakan aktifitas di dalam bangunan ketika aktifitas tersebut tidak dapat dilaksanakan karena adanya sinar matahari yang berlebihan dan turunnya hujan serta angin. Diwujudkanya sebuah bangunan oleh masyarakat tradisional diharapkan bisa merespon iklim tropis tersebut ketika tidak menunjang terlaksananya aktifitas masyarakat tradisional. Maka dengan adanya modifikasi bentuk dilakukan sehingga bisa merubah menjadi iklim dalam ruang yang lebih baik, sehinga seluruh aktifitas masyarakat tradisional dapat diselenggarakan dengan baik.

Aspek topis merupakan hal yang sangat penting dalam mendirikan bangunan, pengaruh fisik pada bangunan sangat menentukan sekali terhadap bagai mana bangunan tersebut bisa maksimal dalam merespon iklim tropis tersebut. Penanganan iklim tropis tersebut akan menghasilkan kenyamanan pada penggunaan bangunan tradisional oleh masyarakat lokal, pengolahan bentuk fisik bangunan tersebut merpakan hal yang sudah berlangsung sangat lama dengan keterampilan yang dilakukan oleh masyarakat itu sendiri.

Proses mendirikan bangunan merupakan tradisi dan cara tersendiri yang dilakukan oleh masyarakat tradisional, merupakan hal yang diwarisi secara turun temurun dari generasi sebelumnya yang telah melalui kondisi alam tropis yang ada pada lingkungan binaan mere kasing masing. Mendirikan bangunan bagi masyarakat tradisional bisa dilihat dari dua faktor yaitu faktor budaya dan lingkungan seperti konstruksi, bahan bangunan yang digunakan, cara membangun serta iklim itu sendiri.

Aspek iklim tropis inilah yang dikaji dengan berapa besarnya penerapan yang dilakukan oleh masyarakat tradisional tersebut pada lingkungan binaan, yaitu rumah tradisional yang telah mereka wujudkan dalam bentuk sebuah karya yang sangat berarti bagi mereka dalam menjalankan aktifitas di dalam bangunan rumah, sehingga mendapatkan kenyamanan yang dihasilkan dalam sebuah fungsi ruang dalam bangunan.

\section{Metede Penelitian}


Metode yang dilakukan adalah pendekatan kualitatif yang digunakan dengan pertimbangan bahwa untuk pada saat turun kelapangan dilakukan pengukuran dan identifikasi pada objek, yang dilakukan pada saat observasi adalah:

- Melakukan pengukuran kembali dari objek dan dituangkan dalam bentuk gambar sketsa, serta foto dengan kondisi aktual di lapangan.

- Melakukan wawancana dengan tokoh masyarakat, mendapatkan sejarah dan identitas bangunan lokal.

- Melakukan pengambilan dokumentasi secara tiga dimensi.

\section{Pembahasan dan Hasil}

\subsection{Penggunaan Rumah Panggung.}

Semua bangunan melayu menggunakan bangunan panggung, fungsi dari menaikkan elevasi lantai dari permukaan tanah bukan hanya sekedar berfungsi sebagai menghindari lantai dari adanya pasang surut air atau banjir, dan juga bukan sekedar menghindari dari binatang buas yang akan mengancam, tetapi ini juga merupakan dalam merespon pengaruh dari iklim tropis itu sendiri.

Penggunaan rumah panggung hal yang sangat baik dilakukan pada lingkungan tropis, sehingga bisa menjaga kelemban yang akan ditimbukkan dari tanah. Pemilihan rumah pangung adalah hal yang bertanggung jawab dalam mendesain sebuah rumah (Bangunwijaya, 2000). Dari beberapa pertimbangan seperti : kelembaban udara dan air hujan, dua hal ini adalah musuh utama dalam penggunaan material bangunan terutama bahan kayu yang merupakan bahan utama, ketika mendirikan sebuah bangunan tradisional. Beberapa bangunan tradisional melayu bisa dilihat pada gambar 1 dibawah. 


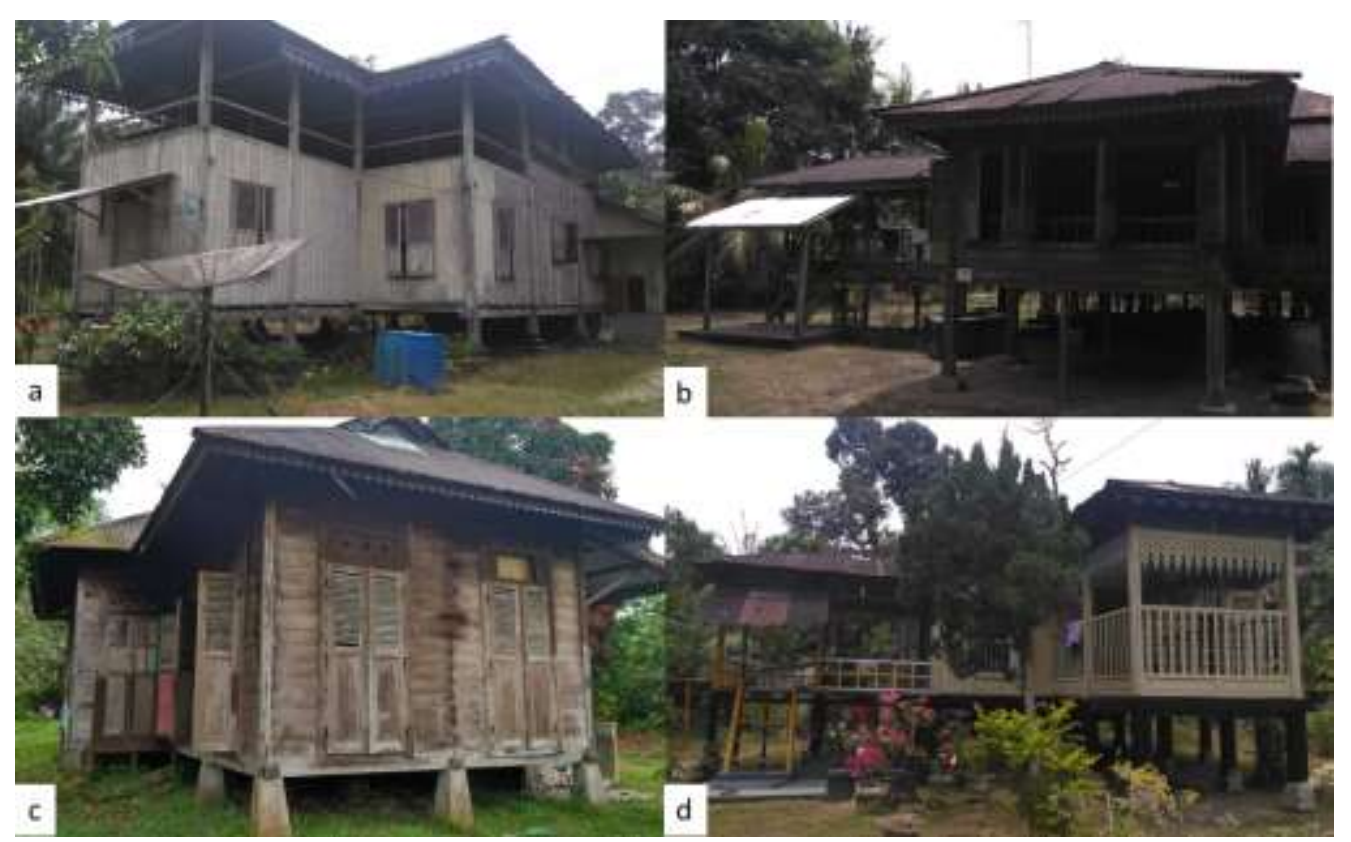

Gambar 1: (a) Rumah ibu Nur,(b) Rumah Kintan, (c) Rumah datuk Mimi, (d) Rumah Wan Subai

Dari beberapa rumah panggung tersebut bisa dilihat ada yang menggunakan beranda dan juga tidak memiliki beranda, yang berfungsi untuk beraktifitas diluar bangunan tetapi tetap berada diatas permukaan tanah dan memiliki pelindung atap dari curahan hujan dan terik matahari. Fungsi teras/selasar/beranda tersebut berfungsi sebagai tempat orang bersantai sore hari sambil mengawasi anak-anak yang bermain dihalaman, dan juga tempat menerima tamu.

Pada bagian bawah bangunan bisa dilihat pada gambar 2. Ruang bawah bangunan (kolong) rumah tradisional memeliki elevasi berpariasi dari atas tanah sehingga penghawaan bawah bangunan bisa tidak terlalu lembab, terlihat kondisi tanah pada bagian bawah kering sehingga tidak terlalu memberikan efek lembab kedalam bangunan dan kepada rangka struktur bawah bangunan yang terbuat dari material kayu pada bagian bawah yaitu: tiang kayu, gelagar induk, gelagar anak serta lantai bangunan.

Dari awah bawah bangunan juga akan bisa kita lihat adanya arus angin yang bisa disebut ventilasi vertical, karena pergerakan angin yang sendirinya melewati pada bagian selah-selah lantai bangunan yang merenggang. Ventilasi ini bisa disebut dengan ventilasi alami sehingga juga bisa menjaga kelembaban ruang dalam bangunan, ventilasi ini sebenarnya juga bisa disiasati ketika melaksanakan konstruksi bawah bangunan dengan 
memperhatikan arah pergerakan angin dan

arah bukaan.

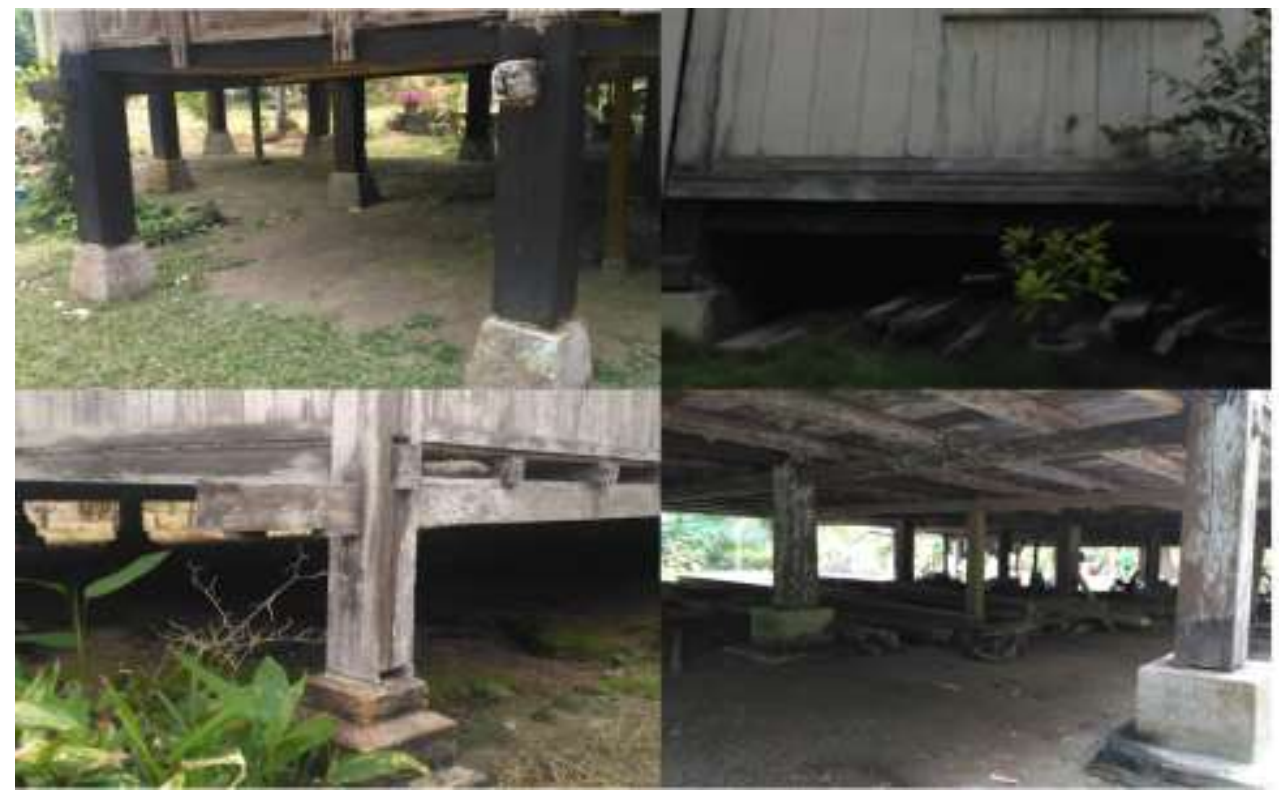

Gambar 2: Kondisi Penghawaan Pada Bagian Bawah Bangunan

Bagian bawah rumah tradisional ini memiliki fungsi yang beraneka ragam seperti: tempat meletakkan barang dan juga tempat anak-anak melakukan aktifitas bermain bersama, sehingga setiap ruang pada banguna tradisional melayu memiliki multi fungsi yang baik, sehingga bisa menampung seluruh aktifitas penggununya.

\subsection{Bukaan Pada Dinding.}

Bangunan arsitektur melayu tradisional adalah merupakan bangunan vernakular, merupakan lingkungan binaan dengan konsep bangunan tropis, dikarenakan bangunan tersebut berada pada kawasan pesisir timur Sumatra sehingga harus bisa merespon lingkungan yang ada pada lokasi bangunan.

Bangunan tersebut banyak memiliki bukaan-bukaan pada dinding, sehingga bisa melakukan control terhadap kondisi tata udara yang berada dalam bangunan, dengan konsep seperti ini bangunan tersebut bisa digolongkan dengan bangunan yang sangat memahami konsidi tropis secara sederhana.

Bukaan tersebut juga berlaku pada dinding dapur dan lantai dapur, sehingga ruang dapur tersebut bisa digunakan dengan maksimal ketika waktu menggunakan tungku untuk memasak. setiap konsep bangunan tradisional memiliki kebutuhan dari pengghuni, 
ketersediaan material, iklim yang ada pada daerah tersebut, tradisi yang berlaku, teknologi yang digunakan pada masa itu.

Bentuk bukaan-bukaan yang ada pada bangunan tersebut bisa dilihat pada gambar 3 dibawah, seperti bukaan pada jendela, ventilasi, pintu, dinding yang dipasang berjarak, serta ornamen pada dinding yang dibuat tembus sehingga dirkulasi udara bisa terjadi, bentuk bukaan kisi-kisi pada dinding sangat banyak memiliki variasi serta memeliki ciri tersendiri dimana posisi penempatannya.

Udara atau kelembaban bisa terkontrol dengan sendirinya pada setiap ruang dalam

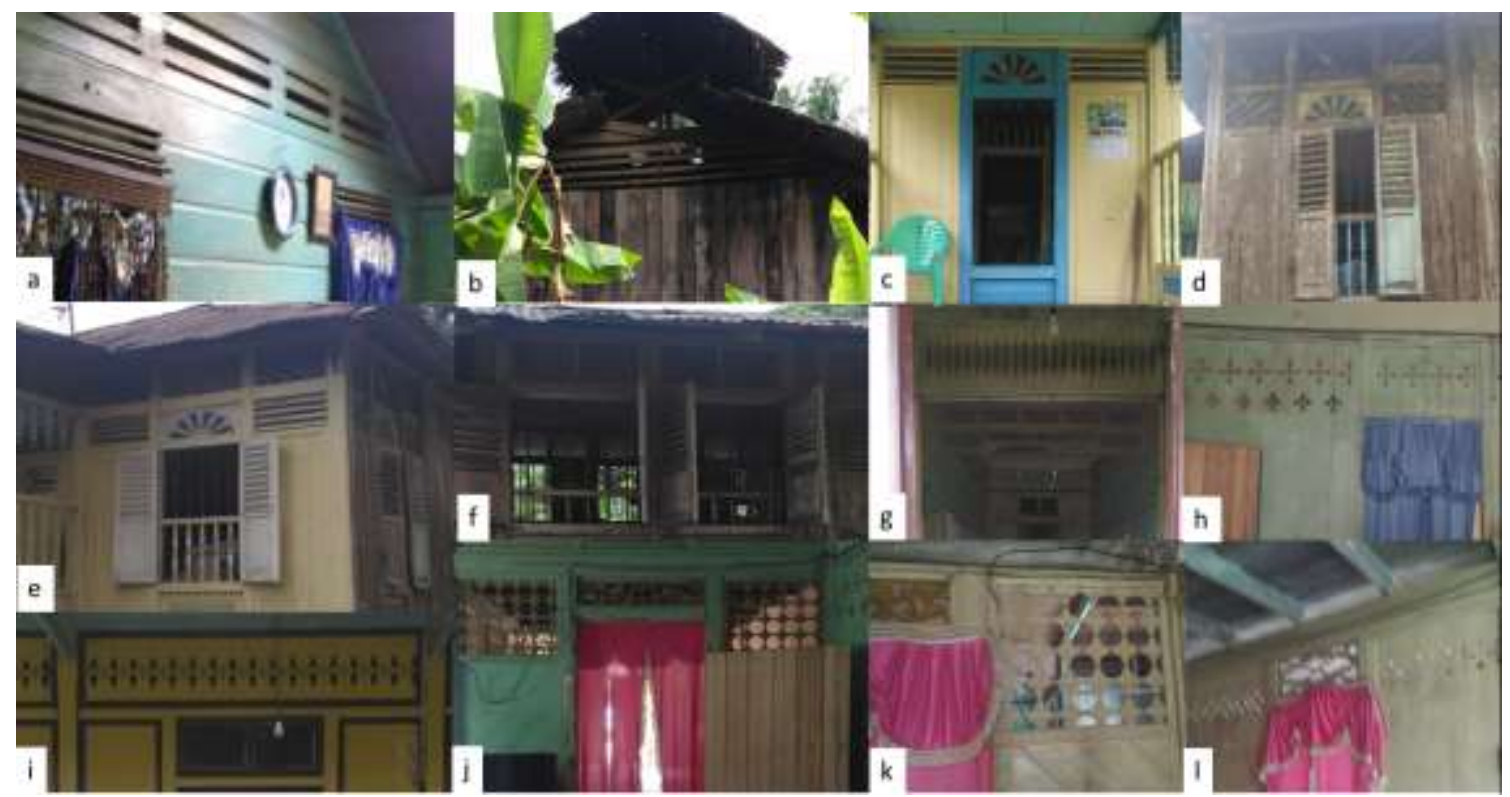

Gambar 3: Bukaan pada bangunan (a) dinding ruang kamar dan ruang tengah, (b) dinding dapur berupa kisi-kisi pada bagian atas, (c) pintu depan dan ventilasi pintu, (d) jendela dan ventilasi jendela serta dinding bagian atas, (e) dinding dibawah atap, (f) jendela dan kisi-kisi sirap, (g) lobang dinding antara ruang depan dan ruang tengah, (h) dinding kamar dan ruang depan, (i) bentuk lain lobang dinding pada pintu depan, (j) bukan dinding ruang tengah dan ruang depan, (k) bentuk lain bukaan dinding dalam, (i) bukaan antara plafon dan dinding dalam bangunan.

Samra, Penerapan Aspek Iklim Tropis pada Arsitektur Lokal Rumah Tradisional Melayu Studi Kasus di Desa Lalang Siak Sri Indrapura 

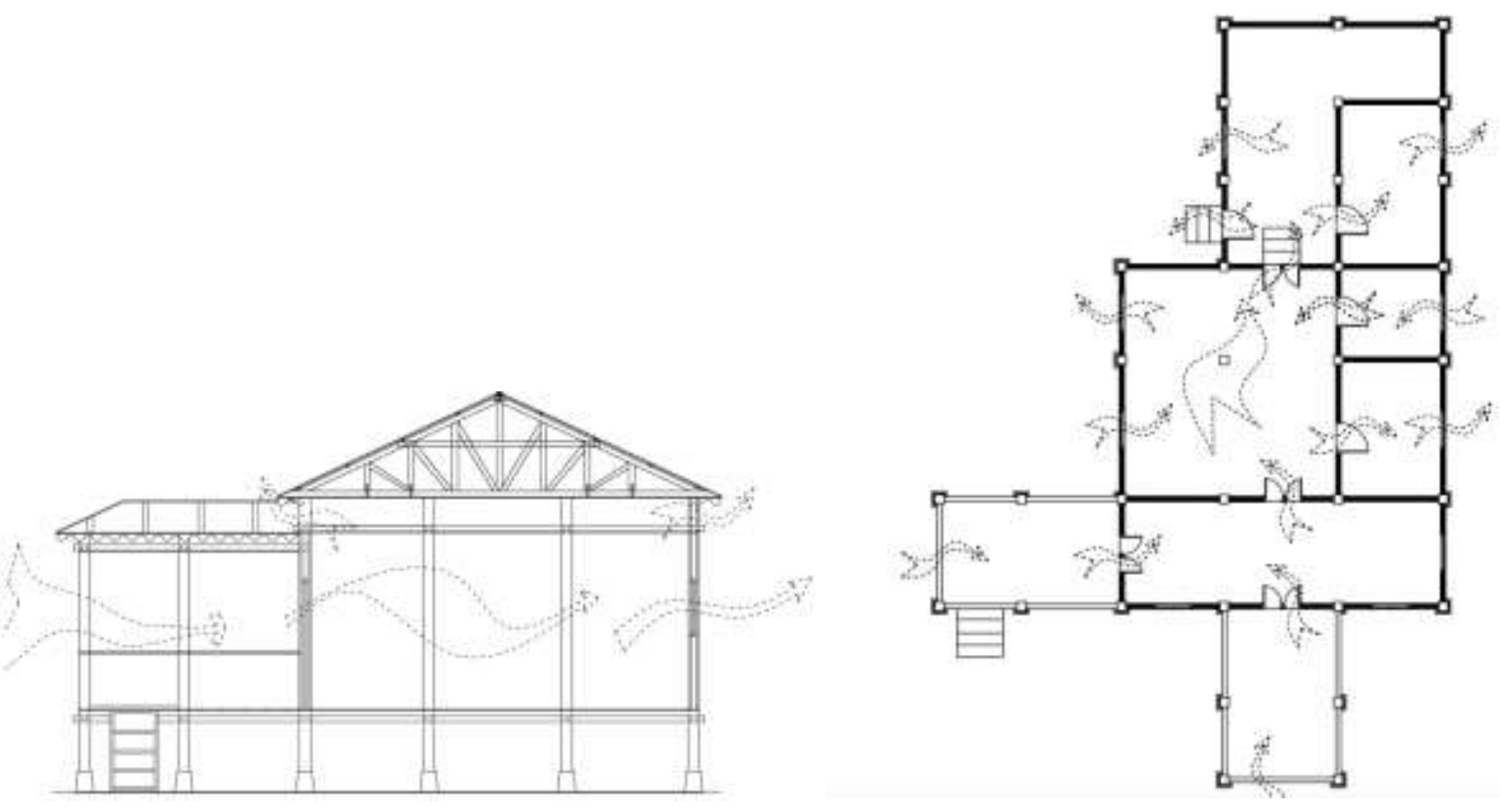

Ganbar 4: Sirkulasi Udara Dalam Rumah Tradisional

Sirkulasi udara yang berlaku pada bangunan ini adalah ventilasi silang, dikarenakan adanya ventilasi diatas jendela bukaan pada dinding yang saling berhadapan, sehingga angin dapat bergerak dan masuk dengan sempurna kedalam bangunan, juga dapat berputar dalam bangunan untuk keluar pada sisi dinding bagian lainnya. Bukan tersebut juga bisa berfungsi secara maksimal dengan masuknya sinar matahari. Pada daerah pesisir timur Sumatra ini tiupan angin cukup keras dan jaraknya juga jauh ke daratan dengan tekanan angin seperti itu juga akan membantu terjaganya kelembaban dalam bangunan, faktor adanya pohon-pohon di sekitar bangunan tradisional juga sangat berpengaruh ketika adanya angin yang bergerak secara negatif.

\subsection{Bentuk Atap Bangunan.}

Atap merupakan salah satu bagian yang sangat penting dalam merespon aspek tropis pada sebuah rumah tradisional, atap sebagai pelindung ruang bangunan dan juga serta perisai bagi dinding bangunan pada bangunan tropis, terutama bangunanbangunan yang menggunakan bahan material utama kayu. Sinar matahari dan curah hujan yang cukup tinggi pada iklim tropis merupakan hal yang harus di 
pecahkan secara baik sehingga tidak menimbulkan persoalan sendiri pada bangunan.

Untuk merespon iklim tropis tersebut bangunan rumah tradisional tersebut memiliki atap yang cukup melebar keluar melebihi dinding paling luar bangunan, sehingga atap tersebut dapat mengatasi sinar matahari yang masuk secara langsung, dan juga pada saat hujan turun atap tersebut akan bisa mengalirkan air cukup jauh dari dinding sehingga dinding bisa terjaga dari faktor kelembaban.
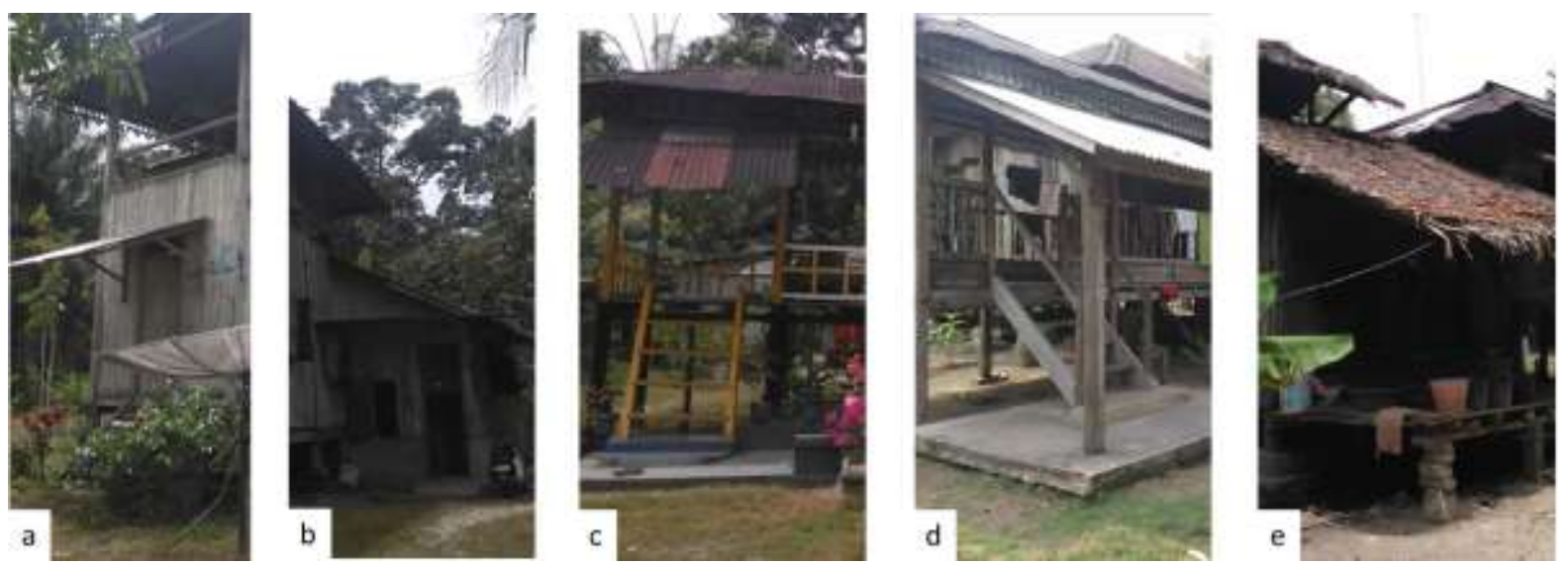

Gambar 5: (a) penutup tangga depan, (b) penutup pintu jendela samping, (c) penutup tangga beranda, (e) penutup beranda pada dapur.

\subsection{Aspek Lingkungan}

Aspek yang juga sangat penting dalam mengendalian angin, curah hujan dan panas matahari terhadap bangunan adalah lingkungan sekitar dimana bangunan rumah tersebut di wujudkan, seperti adanya
Implementasi pada rumah tradisional ini bisa terlihat dari gambar 5 dibawah, pada bangunan tersebut bukan hanya sekedar adanya pelebaran atap dari dinding tetapi juga dapat ditemukan adanya penambahan atap yang berbentuk perisai pada bangunan tersebut, perisai ini digunakan ketika bangunan tersebut memiliki atap yang cukup tinggi sehingga perlu penambahan sehingga bisa menaungi bangunan yang berada pada bagian bawah. 


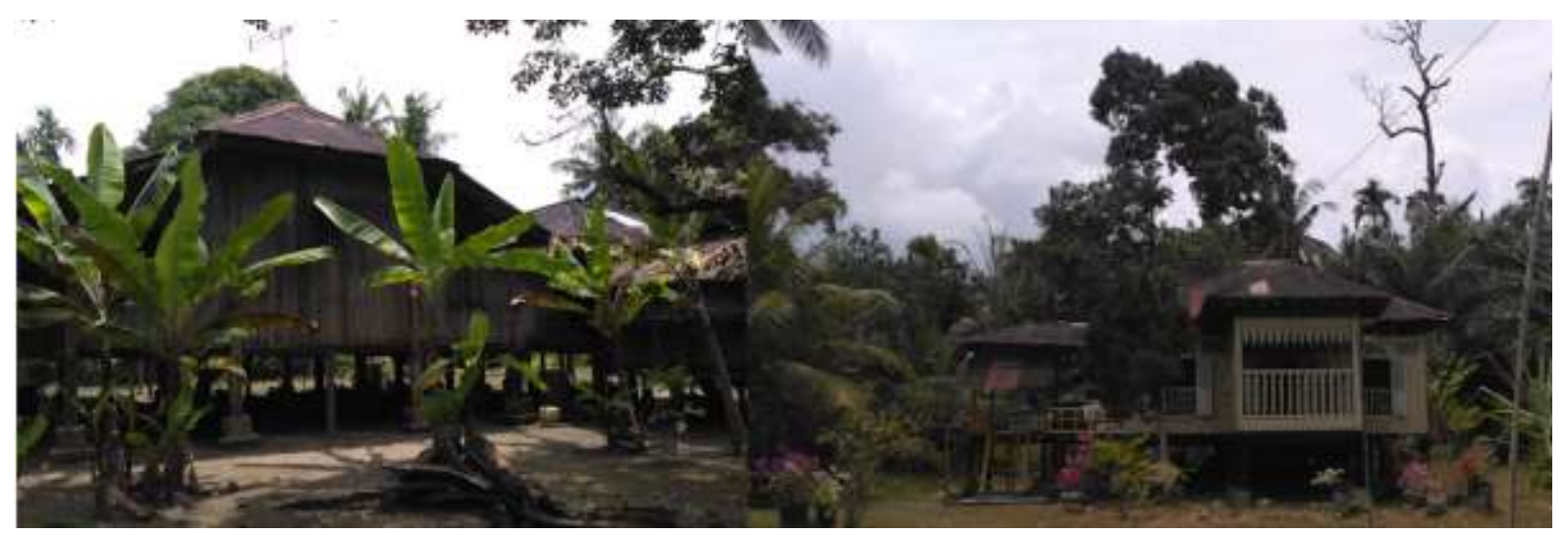

Gambar 6: Adanya Pohon dan Tumbuhan Peneduh Pada Lingkungan.

Angin yang berhembus kearah bangunan akan berkurang kekuatannya ketika mendekati bangunan, ini merupakan salah satu hal yang bisa mengatur seberapa besar bukaan yang bisa dilakukan pada sisi kulit bangunan tradisional itu sendiri,

\section{Kesimpulan}

Bangunan rumah tradisional melayu sangat baik sekali bagaimana bisa merespon dengan baik dari iklim tropis ini, bisa dilihat dengan jelas bagaimana aspek tropis tersebut di terapkan dalam merencanakan bangunan tradisional melayu itu sendiri, beberapa penerapan yang dilakukan dari bentuk fisiknya yaitu: pembuatan bangunan dengan panggung, adanya bukaan pada dinding luar dan dalam bangunan, penggunaan bentuk atap dan penataan pohon pelindung yang ditempatkan pada sisi-sisi bangunan, walaupun pembangunannya dilakukan dengan mekanisme pengetahuan turun temurun dari generasi ke generasi.

\section{Reference:}

1) Effendi,T. (2002). Dasar-dasar bangunan tradisional Melayu Riau

2) Effendi,T. (2013). Lambang dan Falsafah dalam seni bina melayu

3) Bangunwijaya, Y. . (2000). Pengantar Fisika Bangunan. DJAMBATAN.

4) Riau, Departemen Pendidikan dan Kebudayaan (1986) Arsitektur Tradisional Melayu Daerah Riau

5) Samra, B. (2015). Konsep Ruang Dalam Rumah Lama di Kawasan Senapelan Pekanbaru. Jurnal Arsitektur (Arsitektur Melayu Dan Lingkungan), 2(2503-3859), 23-36.

6) Sardjono, A. B. (2011). Respon Rumah Tradisional Kudus Terhadap Iklim Tropis. MODUL, 11(1).

7) Karyono, T. H. (2000). Mendefinisikan kembali Arsitektur tropis di Indonesia. Majalah Desain Arsitektur, 1, 7-8 